\title{
Teachers' Competencies in Teaching and Learning History
}

\author{
Mohd Fauzi Bin Ali', Abdul Razaq Ahmad1, Ahmad Ali Seman² \\ ${ }^{1}$ Faculty of Education, The National University of Malaysia, Bangi, Selangor, Malaysia \\ ${ }^{2}$ Faculty of Social Sciences and Humanities, The National University of Malaysia, Bangi, Selangor, Malaysia \\ Email:fauzinami@gmail.com,razaq@ukm.edu.my, aliseman87@gmail.com
}

How to cite this paper: Ali, M.F.B., Ahmad, A.R. and Seman, A.A. (2017) Teachers' Competencies in Teaching and Learning History. Open Journal of Social Sciences, 5, 220-228. https://doi.org/10.4236/jss.2017.58018

Received: July 25, 2017

Accepted: August 21, 2017

Published: August 24, 2017

Copyright ( $) 2017$ by authors and Scientific Research Publishing Inc. This work is licensed under the Creative Commons Attribution International License (CC BY 4.0).

http://creativecommons.org/licenses/by/4.0/

Open Access

\begin{abstract}
This article reviews the teachers' competencies in teaching and learning History which focuses on contribution of teachers' knowledge towards application in teaching and learning process namely pedagogy, patriotism, teaching aids, information communication and technology (ICT) and curriculum contents. This survey adapted questionnaire as the main instrument. Stratified random sampling technique was utilized to randomly select 850 teachers of secondary school from four different zones in Malaysia. The data was analyzed using SPSS version 22.0 involving multiple regression analysis. The results of the pilot study show that all constructs were examined at the reliability level of between 0.794 to 0.832 . The analysis revealed that all application aspects showed a significance correlation with knowledge competence. Findings showed that the teacher's knowledge about the application of History pedagogical competence gave the highest contribution as compared to the patriotism, the use of teaching aids and information and communication technology (ICT) as well as curriculum content. This study implies that a more systematic and holistic program should be formulated and implemented to ensure that the teachers will fully master the strategies, techniques and methods which are the key aspects of professionalism for History teacher.
\end{abstract}

\section{Keywords}

History Education, Patriotism, Teaching Aids, History Curriculum

\section{Introduction}

History is currently a subject with the high recognition in the national education curriculum. This is because there are subjects that were dropped and became elective subjects. In fact, there are subjects that are amalgamated and assimilated 
in any subject such as geography and Malay literature is inserted into Bahasa Malaysia as a component of Malay literature or known as KOMSAS which is learned in accordance with Bahasa Malaysia subjects. The fate of History subject is much different from other subjects, especially with the introduction of the Secondary School New Curriculum (KBSM) in 1989. These subjects were made as core subjects, which must be studied by all students in high school from Form One to Form Five. According to Rahshdi Ramlan, Deputy Director of Education Malaysia (2001), the prestigious position of this subject is the result of the government's efforts to uphold the subjects that can help the government towards the development of quality citizens. The same goes for other western countries like the United States and England. In fact, in this 21st century, the Malaysian government has made it compulsory for all students who are in Form 5 to pass to this subject in order to obtain the Certificate of Education Malaysia (SPM). At the same time, however, there are still some voices which argue the competencies or proficiency of History teachers in conducting the teaching and learning process in the classroom. The issues in teaching History such as uninteresting subject, chalk and talk, boring, irrelevant and weak patriotism are still happening as revealed through seminars, workshops, reports and journals (Abdul Rahim, 2000 [1]; Abdul Razaq et al., 2013 [2]; Ahamad Rahim, 2013 [3]; Ahmad Ali, 2012) [4]. Therefore, it is vital for a study to be conducted to identify the situation whether the competency of History teachers in the field of pedagogy is still happening. History education plays an important role in the government's effort to build a sovereign nation of Malaysia (Ministry of Education, 2000) [5].

\subsection{Issues in Teaching and Learning History}

The issue pertaining to the context of teaching and learning History in the classroom is where teachers are still using the traditional approaches in teaching process. The traditional approach process is the teaching and learning revolved around the teacher which is also known as "teacher centered" learning and emphasizes the mastery of knowledge or historical facts. This is clearly evident in the Monitoring Report by the Federal Education Inspectorate. According to the Monitoring Report by the Federal Education Inspectorate, the teaching and learning of History subject has not changed much because it is still teachers-centered and does not involve students in the teaching and learning process. Students are also less interested in learning History because the focus is only on the acquisition of knowledge and the use of memorization methods.

\subsection{Pedagogical Knowledge Competency}

The concept of Pedagogy Knowledge Competency refers to the teaching and learning process which emphasizes on the teachers' creativity through their knowledge and skills to create an interesting teaching and learning climate through the mastery of learning materials and skills in strategies, approaches and teaching methods (Shulman, 1987) [6]. Meanwhile, Mohd Johdi (2003) [7] ex- 
plained that among teachers' knowledge domain is the pedagogical knowledge of the content which comprises of four components, namely knowledge about conception and the purpose of teaching a subject, knowledge on student understanding, knowledge about curriculum and knowledge on teaching strategy. Mohd Khairuddin et al. (2014) [8] also asserted the aspects that should be emphasized is the process of teaching which involves planning and delivering the knowledge from the teacher to the students. Effective teaching is derived from the teacher's skill which successfully matches the teaching methods with student's learning objective as well as their learning style. The Curriculum Development Division, Ministry of Education Malaysia (2013) [9] also recommends History teachers to tailor their teaching and learning with the latest teaching methods such as future studies, multiple intelligence methods, constructivism methods, contextual methods, and historical thinking method to make an interesting and meaningful learning.

\subsection{History Textbook}

Textbooks are also an issue among History teachers and students. This is because the textbook is their main book. Most of the activities and teaching of history in schools are based on textbooks. The notes given are entirely quoted from the textbook provided by the Ministry of Education. Usually, the teachers will ask the students to read the book and outline certain sections and facts which they consider will be important for the upcoming exam. The issue is that the teacher rarely exposed their students with other historical sources but rather chose to rely on textbooks (Jagdish Raj Sharma, 1990) [10].

According to a study conducted by Doreen Tan (2004) [11] in Perak, the teachers faced difficulties in using teaching aids (ABM) in teaching History due to the difficulty in obtaining the material, particularly replicas and historical material models. History textbooks are also considered as non-user-friendly because they do not attract the reader attention. Adolescent readers which comprises of high school students require interesting reading material. If the book writing is loaded with ideas and mere facts without including the illustrations and graphic, the interest to further read the materials will diminish. History syllabus and extensive textbook content also result in students failing to master historical knowledge.

\subsection{Pedagogical Skills of History Teachers}

Although there is an alternative to improve the quality of the educational curriculum of history but the pedagogy remains unchanged. This is an issue that should be scrutinized by the curriculum designer. According to the Special Committee Report on Reviewing Teaching and Learning Objectives of History at Secondary Schools, there was no significant difference in the teaching and learning of the Secondary School Curriculum History with the previous Secondary School Curriculum. The usual practice in the classroom such as one-to-one 
teaching and learning pattern from teacher to student and historical fact-finding in History teaching is still ongoing in the curriculum system. This is very disappointing because according to the curriculum system the learning pattern emphasizes students-centered learning. According to Aini Hassan (1992) [12], teachers use most of the time in class to talk and explain. Too little involvement of students except to answer the teacher's questions, which is also a re-spell of what the teacher said earlier. This causes the students to be more motivated to memorize the contents of the lesson than to understand and master the content. According to Hallam (Wineburg, 2001) [13], children thoughts are often disrupted by thinking about abstract concepts and events, especially those that are out of their mind box.

\section{The Purpose of the Study}

The purpose of this study is to examine and identify the main contribution of teachers' knowledge competency which comprises of the contents of History curriculum, pedagogy, historical thinking, patriotism value, teaching aids and ICT towards the application of History teacher consisting of historical pedagogy, application of patriotism, use of teaching aids and ICT as well as curriculum content. Competency refers to a set of knowledge, skills and work value which is strong, quality and complementing job procedures as a professional officer which fulfil the job accountability and career as a teacher (Esah Sulaiman, 2003 [14]; Boyatzis, 1982) [15].

\section{Methodology}

This study uses quantitative approaches through survey method using questionnaire. A pilot study was conducted involving 80 History teachers to obtain the credibility and reliability of the research instrument. The pilot study showed the Alpha cronbachvalues for each component studied is between 0.785 and 0.957. This shows that every item and instrument that were used has high reliability level. This study involved 850 History teachers based on the Krecjie \& Morgan sampling schedule (1970) [16] comprising the northern zone in Penang ( $\mathrm{n}=$ $200)$, the eastern zone in Pahang $(\mathrm{n}=220)$, the central zone in Selangor $(\mathrm{n}=$ $230)$ and south zone in Negeri Sembilan $(\mathrm{n}=200)$. A total of $282(33.2 \%)$ male teachers and $568(66.8 \%)$ female teachers were involved in the study. The data were collected using questionnaire to obtain information from respondents. The questionnaire in this study uses the Likert scale 1 to 5 . All question items in this section contain five choices of answers that are set as Very Disagree, Disagree, Less Disagree, Agree and Strongly Agree. This study contains 120 items comprising four main constructs: Part A: demography (6 items), Part B: Teacher's Knowledge on History Curriculum Content (40 items), Part C: Teacher's Knowledge (37 items) and Part D: History teacher competency (37 items). Descriptive analysis was used to describe the overall profile of the respondents and to answer the questions of the study. Interpretation of the scores used is 1.00 to 2.33 (Low), 
2.34 to 3.67 (Medium) and 3.68 to 5.00 (High) (Jamil 2002) [17]. To analyse the contribution of each variable, multiple regression analysis has been used. The data were analyzed using SPSS version 22.0 software.

\section{Results and Discussion}

\subsection{The Contribution of Teacher's Knowledge Competency towards Competency Application}

Multiple regression analysis is carried out to identify the contribution of teachers' knowledge to their applications of competence among History teacher. Some data that can interfere with the reliability of the findings of regression was dropped (through analysis Casewise diagnostics). In addition, some linear regression assumptions such as variance test and normality tests as well as colonearity aspects are also carried out according to the specified method (Hair et al., 2006) [18].

Table 1 shows the stepwise regression analysis that has been conducted revealed pedagogical knowledge of history $(F=243610$, Sig. $=0.000)$, knowledge of patriotism application $(\mathrm{F}=177 \mathrm{145}$, Sig $=0.000)$, knowledge of using teaching aids and ICT $(F=124,227$ and sig $=0.000)$ and knowledge in History curricu$\operatorname{lum}(\mathrm{F}=98.490, \mathrm{Sig}=0.000)$ is a significant variant which is a predictor towards History teacher's competency application. Contribution given by every aspect of History teacher's knowledge on their competency application is listed as Table 1 below.

Table 1 shows that knowledge on history pedagogy accounted for 22.3 per cent $\left(\right.$ Beta $=0.320, t=10.022$, Sig. $=0.000$ and $\left.\mathrm{R}^{2}=0.223\right)$. Knowledge on patriotism value contributed 7.2 per cent (Beta $=0.145, \mathrm{t}=3.294$, Sig. $=0.000$ and $\mathrm{R}^{2}=0.295$ ), teaching aids and ICT usage accounted for 1.1 per cent (Beta $=$ $0218, \mathrm{t}=4.807$, Sig. $=0.000$ and $\left.\mathrm{R}^{2}=0.306\right)$ and history curriculum content

Table 1. Multiple regression of History teacher's knowledge competency contribution towards competency application.

\begin{tabular}{|c|c|c|c|c|c|c|c|}
\hline \multirow{2}{*}{$\begin{array}{c}\text { History } \\
\text { teacher } \\
\text { application } \\
\text { variable }\end{array}$} & \multicolumn{2}{|c|}{$\begin{array}{l}\text { Unstandardized } \\
\text { Coefficients }\end{array}$} & \multirow[t]{2}{*}{$\begin{array}{l}\text { Standardized } \\
\text { coefficients }\end{array}$} & \multirow{2}{*}{$\mathrm{T}$} & \multirow{2}{*}{ Sig. } & \multirow{2}{*}{$\mathrm{R}^{2}$} & \multirow{2}{*}{ Contribution } \\
\hline & B & $\begin{array}{l}\text { Standard } \\
\text { error }\end{array}$ & & & & & \\
\hline Pedagogy & 0.208 & 0.021 & 0.320 & 10.022 & 0.000 & 0.223 & $22.3 \%$ \\
\hline $\begin{array}{c}\text { Application } \\
\text { of patriotism } \\
\text { value }\end{array}$ & 0.092 & 0.028 & 0.145 & 3.294 & 0.001 & 0.072 & $7.2 \%$ \\
\hline $\begin{array}{c}\text { Use of } \\
\text { teaching aids } \\
\text { and ICT }\end{array}$ & 0.186 & 0.039 & 0.218 & 4.807 & 0.000 & 0.011 & $1.1 \%$ \\
\hline $\begin{array}{l}\text { Curriculum } \\
\text { content }\end{array}$ & 0.004 & 0.001 & 0.118 & 3.883 & 0.000 & 0.011 & $1.1 \%$ \\
\hline Constant & 1.604 & 0.134 & & 12.004 & 0.000 & & \\
\hline
\end{tabular}


knowledge contributed 1.1 per cent $\left(\right.$ Beta $=0.118, \mathrm{t}=0.118$, Sig. $=0.000$ and $\mathrm{R}^{2}=$ 0.318). In this context, it is possible that the rest of the remaining percentage of about 29.4 percent is further contributed by other factors towards the student's soft skills which were not taken into account in this study (Pallant, 2007) [19].

\subsection{Discussion}

Multiple regression analysis shows that the historical pedagogical knowledge, the application of patriotism values, the knowledge of using teaching aids and ICT and the knowledge on historical curriculum content contributes to the application of History teacher competence. This means that deeper and more extensive disclosures about these aspects need to be enhanced by the History teachers especially to implement such competency applications. The results showed that pedagogical knowledge contributed the most in competence applications. In line with Nik Mohd Rahimi's statement (2012) [20], pedagogical competence knowledge is the most important thing to be mastered by teachers in the process of teaching and learning in the classroom. With teachers' pedagogical competence, they can motivate students to learn. The findings are also in line with the statement from Mohd Mahzan, Abdul Razaq Ahmad \& Mohd Muhaimi (2014) [21] which stated that teachers need to take various initiatives in diversifying the teaching methodology and teaching techniques to facilitate the understanding of students in learning the History subject. The lack of creative elements in teaching History makes students less interested in this subject. In addition, the absence of innovation in the teaching process at school also causes students to feel the History subject is not challenging and static.

On the other hand, the application of patriotism value is the second highest contributor to the application of History teachers by $7.2 \%$. This suggests that historical teachers apply the value of patriotism in the process of teaching history in the classroom. The findings of this study in line with the study of Chua Kheng Hoe (2007) [22] show that teachers are embracing the elements of patriotism in teaching in the classroom although it does not take long. This is in parallel with the statement from Abdul Razaq et al. (2013) [2] which argue that teachers play an important role in instilling and developing patriotic spirit through exposure and appreciation. This process will give a profound and deep understanding of patriotism.

The usage of teaching aids and ICT as well as curriculum content respectively contributed by $1.1 \%$ of the total value. This shows that History teachers are still lack in using teaching aids and ICT in the teaching process in the classroom. The findings are consistent with the study of Anuar Ahmad, SitiHaishah Abd Rahman \& NurAtiqah T. Abdullah (2009) [23] which shows that there are still some History teachers who still have phobia, fear and negative attitude as they prefer the old method based on textbooks, circular notes or writing on blackboard only. Moreover, the knowledge on history curriculum content is still need to be improved among the History teachers. The findings are also consistent with the 
study of Rosnanaini (2003) [24] which stated that teachers' current teaching methods are heavily influenced by examination requirements as well as completing syllabus. Students have less room to applying their knowledge of history in a more creative form because of school culture which emphasizes academic achievement rather than the student development process of creativity (Hooper \& Rieber 1999) [25].

\section{Implications and Recommendations}

Through this study, it is possible to provide new inputs to History teachers as the basis of the competence standard among History teachers which are required to produce a quality, effective, excellent and excellent History teachers. To achieve the standard level of competence or the special efficiency level, three main elements of the competencies such as subject matter knowledge on History discipline has to be mastered efficiently so that the teachers are able to be referred to as an expert in the subject of history. In addition, the teachers have to act as a problem solver when historical issues are raised especially about the history of the country, whether at the national or international level. History teachers are not only have a basic knowledge of history but also needs to know in depth and explore the historical information in greater depth so that the historical knowledge can be informative as well as served as little historian who can act as small historian inside and outside of the classroom.

Therefore, the parties which are directly involved in empowering teachers such as the Curriculum Development Division (IRB), the State Education Department and District Education Office have to provide training, hands-on workshops for History teachers. In fact, research from Rosnanaini (2003) [24] urges courses and training to emphasize practical practice because teachers who attended the course are still lack in confidence to carry out historical thinking because the knowledge of implementation is still blurry. This should be taken seriously because history education is a compulsory subjects studied by all secondary school students in Malaysia (Ministry of Education, 2013) [26]. The student's aspirational aspect as suggested in the Malaysian education development plan needs to be achieved so that the young generation that were born in the History curriculum era can become avisionary, calibre and democratic leader which have a superior identity.

\section{Conclusion}

This study identified that History teachers' competency in Malaysia at high school level is still unsatisfying in the aspects of patriotism implementation among students in History subject. The use of teaching aids is still focusing on traditional methods in teaching and learning History in the classrooms. In order to improve those aspects, teachers should enhance their knowledge and skills in Informational and Communication Technology (ICT) that can assist in improving students' motivation and interest in learning History. Hence, the school 
administration and ministry levels should provide training on ICT based for the teachers. This study also identified the level of knowledge competence and pedagogical applications among secondary school History teachers in Malaysia. The study found knowledge and application of pedagogical competence among History teachers should be enhanced in parallel with emphasis on teaching and learning History based on student-centered strategy as embedded in the Malaysian Education Development Plan. The Ministry of Education should take action in order to produce professional teachers because less competence teachers in pedagogy can affect the achievement of History educational goals. In-service training programs need to be conducted and focus on teacher competencies either on the collaboration with the Ministry of Education or the university.

\section{References}

[1] Rashid, A.R.A. (2000) Model dan Pendekatan Pengajaran Sejarah KBSM, Kuala Lumpur. Dewan Bahasadan Pustaka.

[2] Ahmad, A.R.M., Awang, M., Seman, A.A. and Abdullah, R. (2013) The Skills of Using History Textbooks in Secondary School. Asian Social Science, 9, 229-236. https://doi.org/10.5539/ass.v9n12p229

[3] Rahim, A. (2013) Penilaian Pelaksanaan Kurikulum Sejarah Menengah Rendah Tingkatan 2. Tesis Doktor Falsafah. Universiti Kebangsaan Malaysia, Bangi.

[4] Seman, A.A. (2012) Sejarah Berteraskan Perspektif Kepelbagaian Budaya Terhadap Pembentukan Integrasi Nasional. Universiti Kebangsaan Malaysia, Bangi.

[5] Ministry of Education. (2000) Teaching and Learning History Modules. Centre of Curriculum Development.

[6] Shulman, L. (1987) Knowledge and Teaching: Foundations of the New Reform. Harvard Educational Review, 57, 1-22. https://doi.org/10.17763/haer.57.1.j463w79r56455411

[7] MohdJohdi (2003) Kurikulum Sejarah Sekolah Menengah. Perspektif Pelajar-Pelajar: Kertas Kerja Pusat Pendidikan Dan Pembangunan Insan, Universiti Islam Antarabangsa, Gombak, Selangor.

[8] Khairuddin, M., Johari, K., Yusof, A. and Laji, H. (2014) Komunikasi Guru Dalam BilikDarjah Dan Tingkah Laku Delinkuen Murid Seklah Menengah. Journal for Educational Thinker, 5, 59-77.

[9] The Curriculum Development Division (2013) Monitoring Reports on the Effectiveness of History Curriculum Implementation in Sabah and Sarawak. Ministry of Education, Putrajaya.

[10] Sharma, J.R. (1990) Latihan Mengajar. Utusan Publication \& Distributors Sdn Bhd, Kuala Lumpur.

[11] Tan, D. (2004) What Is History Teaching and Learning? Teaching and Learning, 25, 197-206.

[12] Hassan, A. (1992) Mata Pelajaran Sejarah KBSM: Apa Yang Baru? Bahagian Pendidikan Guru, Kementerian Pelajaran Malaysia. Jurnal Pendidikan Guru, 8, 83-93.

[13] Wineburg, S. (2001) Historical Thinking and Other Unnatural Acts. Philadelphia University Press, Philadelphia, 35-44.

[14] Sulaiman, E. (2003) Amalan Profesionalisme Perguruan. University of Technology, Malaysia, Sekudai, Johor Baru.

[15] Boyatzis, R.E. (1982) The Competent Manager: A Model For Effective Performance. 
John Dewey, New York.

[16] Krejcie, R.V. and Morgan, D.W. (1970) Determining Sample Size for Research Activities. Educational and Psychological Measurement, 30, 607-610. https://doi.org/10.1177/001316447003000308

[17] Ahmad, J. (2002) Pemupukan Budaya Penyelidikan Dikalangan Guru di Sekolah: Satu Penilaian. Ph.D. Thesis, Fakulti Pendidikan Universiti, Kebangsaan Malaysia, Bangi.

[18] Hair, J.F., Black, W.C., Babin, B.J., Anderson, R.E. and dan Tatham, R.L. (2006) Multivariate Data Analysis. Prentice Hall, Upper Saddle River.

[19] Pallant, J. (2007) SPSS Survival Manual. 3rd Edition, Allen \& Unwin, Wales.

[20] Yusoff, N.M.R.N., dan Nurulhuda, H. and Afifi, M. (2012) Pengetahuan Pedagogi Isi Kandungan (Ppik) Pengajaran Bahasa Arab. Persidangan Kebangsaan Pengajaran Dan Pembelajaran Bahasa Arab. http://www.ukm.my/uba/sebar2012/prosiding.htm

[21] Awang, M.M., Ahmad, A.R. and Rahman, M.M.A. (2014) Penggunaan Peta Mindaoleh Pelajar Pintar Cerdas Dalam Pembelajaran Sejarah. Jurnal Pendidikan Malaysia, 39, 95-100.

[22] Chua, K.H. (2007) Pembangunan Patriotisme Dalam Pengajaran Dan Pembelajaran Mata Pelajaran Sejarah Tingkatan Dua: Perbandingan Antara Empat Jenis Sekolah. Thesis Lengkap Ijazah Sarjana Pendidikan, Fakulti Pendidikan Universiti Teknologi Malaysia, Shah Alam, Selangor.

[23] Ahmad, A., Rahman, S.H.A. and Abdullah, N.A.T. (2009) The Relationship between History Teachers' Level of Capability and Students' Performance in Low Performance Schools.

[24] Sulaiman, R. (2003) Pelaksanaan Pendekatan Pengajaran Kemahiran Berfikir Dalam Mata Pelajaran Sejarah: Satu Kajian Kes. Ph.D. Thesis, Universiti Kebangsaan Malaysia. Bangi.

[25] Hooper, S. and Rieber, L.P. (1999) Teaching, Instruction, and Technology. In: Ornstein, A.C. and Behar-Horenstein, L.S., Eds., Contemporary Issues in Curriculum, Allyn and Bacon, Boston, 252-264.

[26] Ministry of Education (2013) Guidance on Examination Management. Malaysian Examinations Council, Kuala Lumpur.

Scientific Research Publishing

\section{Submit or recommend next manuscript to SCIRP and we will provide best service for you:}

Accepting pre-submission inquiries through Email, Facebook, LinkedIn, Twitter, etc. A wide selection of journals (inclusive of 9 subjects, more than 200 journals)

Providing 24-hour high-quality service

User-friendly online submission system

Fair and swift peer-review system

Efficient typesetting and proofreading procedure

Display of the result of downloads and visits, as well as the number of cited articles

Maximum dissemination of your research work

Submit your manuscript at: http://papersubmission.scirp.org/

Or contact jss@scirp.org 